\title{
地震時のひずみ速度の影響による鉄筋コンクリート部材の 耐力の増大と破壊モードとの関係に関する研究 RELATIONSHIP BETWEEN THE INCREASE OF STRENGTH AND FAILURE MODE OF REINFORCED CONCRETE MEMBERS BY THE STRAIN RATE EFFECT IN AN EARTHQUAKE
}

\author{
細矢 博*, 岡田恒男**, 北川良和***, 中埜良昭****, 隈澤文俊***** \\ Hiroshi HOSOYA, Tuneo OKADA, Yoshikazu KITAGAWA, Yoshiaki NAKANO \\ and Fumitoshi KUMAZAWA
}

\begin{abstract}
During an earthquake, strength of reinforced concrete (RC) members increases greater under dynamic loading than under static loading by the effect of strain rate. The increases of flexural strength and shear strength differ from each other. This may cause a different failure mode from the one, planned in the structural design. In this paper, the relationship between the increase of strength and the change of failure mode of RC members is investigated.

Analytical investigations reported that the strain rate of RC members may be around $10^{4} \sim 10^{5} \mu / \mathrm{sec}$ during an earthquake. Under this strain rate, while the increase ratio of the flexural strength is about $1.15 \sim 1.3$, the one of the shear strength is about $1.15 \sim 1.25$. When axial force is beyond the balanced axial force, the increase ratio of flexural strength is greater than the one of shear strength. To achieve the flexure failure mode irrespective of axial force level, the design shear strength must be $15 \%$ greater than the flexural strength.
\end{abstract}

Keywords: reinforced concrete, earthquake, strain rate, strength, increase of strength, failure mode 鉄筋コンクリート、地震、ひずみ速度、耐力、耐力増大率、破壊モード

\section{1.はじめに}

鉄筋コンクリート造建築物が地震動を受ける際に部材に生じると 想定される最大ひずみ速度のレベルで、部材を構成する材料、す なわちコンクリートと鉄筋の強度は、ひずみ速度の影響を受けて上 昇することが知られているたとえば 1)、2)。しかしながら、地震動を 受けて建築物が振動する場合、首間変形が小さな領域では変形速度 が大きいものの、層間変形のピーク近傍では変形速度が減少し、こ れに伴い部材に生じるひずみ速度も減少する。このため、最大変形 時、換言すると最大耐力時にひずみ速度がどの程度のレベルにあり、 また、どの程度材料強度が上昇するのかなど不明であった。一方、 科学技術庁防災科学技術研究所の大型振動台により、1968 年の十勝 沖地震の際に八戸港湾で記録された地震波を用いて行われた実大 3 層鉄筋コンクリート造立体骨組の振動台実験結果によると、最大耐 力時に架構を構成する柱部材およびはり部材の材端部に生じていた

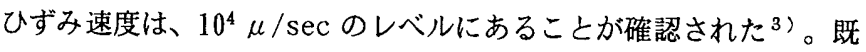
往の研究 ${ }^{1}$ ，2，4）による亡、このひずみ速度のレベルでは、コン クリートの圧縮強度は $20 \%$ 程度、鉄筋の降伏強度は $10 \%$ 程度上昇 することが報告されている。したがって、地震動を受ける建築物の 部材耐力は、静的載荷時の耐力に比較して増大すると予想されるが、 部材酎力の増大率や、耐力の増大と破壊モードとの関係などは十分
に明らかにされたとは言い難い。

このような背景を踏まえ、筆者らは、鉄筋コンクリート（以下、 $\mathrm{R} C$ と称す）柱部材を対象とした静的ならびに動的加力実験結果 4)、 5)や、ひずみ速度の影響による材料強度の上昇を考慮したファイバ 一モデルによる断面解析結果 ${ }^{6}$ )から、部材耐力や破壊性状に及ぼす ひずみ速度の影響について報告してきた。しかしながら、既往の研 究も含め、未だ地震時における R C 部材の耐力の增大と破壊モード との関係については検討が不十分であるといえる。そこて、、本論て は、上記の実験結果や解析結果から、R C 部材の曲げ耐力ならびに せん断耐力の増大率とひずみ速度との関係、それらの耐力の増大率 と破壊モードとの関係をさらに検討したので、以下に報告する。

\section{2. 静的ならびに動的水平加力実験}

\section{1 実験概要}

(1) 加力実験シリーズおよび試験体

試験体の諸元を表 1 に、試験体の形状・寸法および配筋の代表例 を図 1 に示す。加力実験は、目標軸力を軸力比 $\left(\eta=\mathrm{N} / \sigma_{\mathrm{B}} \mathrm{bD}\right)$ にし て0.3に設定したシリーズ I と、 $\eta=0.02 \sim 0.03 （ \mathrm{~N}=5.2 \mathrm{tf}$ ）に設定 したシリーズIIか成る。試験体は、シリーズ I では曲げ破壊型に 計画されたMタイプとせん断破壊型に計画されたSタイプから成り、

\footnotetext{
本諭文の一部は, 文解4)〜6)で発芘している。

** 芝浦工業大学工学部漖授・工搏

***広島大学:工学部教变・工博

***** 東京大学生廉技術研究所 助教授・ 工博

***** 建設省建築研究所 主任研究員・博士 $($ T.学
}

Research Engineer, Technical Research Institute, Okumura Corp., Dr. Eng. Prof., Faculty of Engineering, Shibaura Institute of Technology, Dr. Eng. Prof., Faculty of Engineering, Hiroshima University, Dr. Eng. Assoc. Prof., Institute of Industrial Science, University of Tokyo, Dr. Eng. Research Engineer, Building Research Institute, Ministry of Construction, Dr. Eng. 
シリーズIIては全てせん断破壊型に計画された S タイプから成る。 Mタイプは 1 種類の配筋モテル、Sタイプは 5 種類の配筋モテルて ある。各試験体の柱部分の断面寸法は250mmx $250 \mathrm{~mm}$ であり、柱高さ

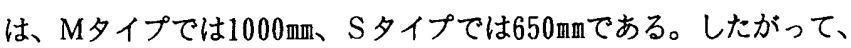
シアスパン比は、Mタイプでは2.0、Sタイプでは1.3でる。なお、 試験体は、各配筋モテルごとに静的加力用と動的加力用を対で製作 した。

表 1 試験体諸元

\begin{tabular}{|c|c|c|c|c|c|c|c|}
\hline \multirow{2}{*}{\multicolumn{2}{|c|}{ 試験体タイプ }} & \multicolumn{2}{|c|}{ シリーズI } & \multirow{2}{*}{\multicolumn{4}{|c|}{$\frac{\text { シリーズII }}{\text { Sタイプ }}$}} \\
\hline & & \multirow{2}{*}{$\frac{M タ イ フ ゚ ~}{M S F-1}$} & \multirow{2}{*}{$\frac{\text { Sタイプ }}{\text { SSF-1 }}$} & & & & \\
\hline \multirow{2}{*}{ 試験体記号 } & $\begin{array}{l}\text { 静 } \\
\text { 的 }\end{array}$ & & & SSC-2 & SSC-3 & SSC-4 & SSC-5 \\
\hline & $\begin{array}{l}\text { 動 } \\
\text { 的 }\end{array}$ & $\begin{array}{l}\text { MDF-1 } \\
\text { MDF-2 }\end{array}$ & $\begin{array}{l}\text { SDF-1 } \\
\text { SDF-2 }\end{array}$ & SDC-2 & SDC-3 & SDC-4 & SDC-5 \\
\hline$b \times D$ & $(\mathrm{~mm})$ & $250 \times 250$ & $250 \times 250$ & \multicolumn{4}{|c|}{$250 \times 250$} \\
\hline \multicolumn{2}{|r|}{$(\mathrm{mm})$} & 1000 & 650 & \multicolumn{4}{|c|}{650} \\
\hline \multirow{2}{*}{\multicolumn{2}{|c|}{ 柱主筋 }} & $12-D 13$ & $12-D 13$ & $12-016$ & \multicolumn{3}{|c|}{$16-D 16$} \\
\hline & & [SD295A] & [SD295A] & [SD345] & \multicolumn{3}{|c|}{ [SD345] } \\
\hline $\mathrm{Pg}$ & (\%) & 2.438 & 2.438 & 3.821 & \multicolumn{3}{|c|}{5.094} \\
\hline $\mathrm{Pt}$ & (\%) & 0.813 & 0.813 & 1.274 & \multicolumn{3}{|c|}{1.592} \\
\hline \multirow{2}{*}{\multicolumn{2}{|c|}{ フープ筋 }} & $4-D 6 @ 40$ & $2-D 6 @ 50$ & \multirow{2}{*}{\multicolumn{2}{|c|}{$\begin{array}{l}2-D 6 @ 50 \\
{[S D 295 A]}\end{array}$}} & 3-D6@50 & 4-D6@50 \\
\hline & & [SD295A] & [SD295A] & & & [SD295A] & [SD295A] \\
\hline & $(\%)$ & 1.280 & 0.512 & \multicolumn{2}{|c|}{0.512} & 0.768 & 1.024 \\
\hline \multicolumn{2}{|c|}{ 涌パ 比 [M/OD] } & 2.0 & 1.3 & \multicolumn{4}{|c|}{1.3} \\
\hline \multicolumn{2}{|c|}{ 目標軸力比 $[n]$} & $0.3^{3]}$ & $0.3^{3]}$ & \multicolumn{4}{|c|}{$0.02 \sim 0.03$} \\
\hline \multicolumn{2}{|c|}{ せん断余裕率 ${ }^{1]}$} & 1.28 & 0.84 & 0.92 & 0.80 & 0.84 & 0.89 \\
\hline \multirow{2}{*}{$\begin{array}{l}\text { 層間変形 } \\
\text { 速度 }^{2]}\end{array}$} & 静的 & \multicolumn{2}{|c|}{$0.01(\mathrm{~cm} / \mathrm{sec})$} & \multicolumn{4}{|c|}{$0.01(\mathrm{~cm} / \mathrm{sec})$} \\
\hline & 動的 & 10.010 & $\mathrm{~m} / \mathrm{sec})$ & \multicolumn{4}{|c|}{$10.0(\mathrm{~cm} / \mathrm{sec})$} \\
\hline
\end{tabular}

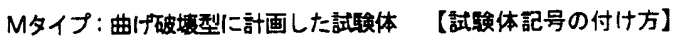

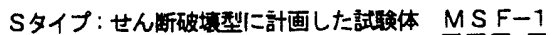

$b$ : 挂幅、 $D$ : 柱成、 $\mathrm{h}$ : 挂高さ不不不番号

$\eta=\mathrm{N} /\left(\sigma_{B} \cdot b \mathrm{D}\right)$

$\eta:$ 軸力比、 $\mathrm{N}:$ 䌷力

$\sigma_{B}:$ コンクリート压縮強度

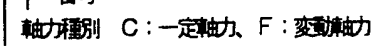
加力速度 $S:$ :

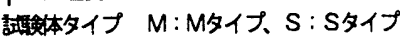

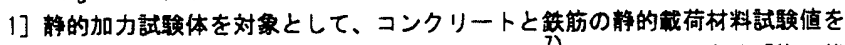
用い、曲げ耐力式 [建笑センター式(式 6-3e) $\left.{ }^{7}\right]$ とせん断耐力式 [佫正充

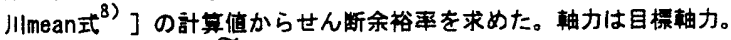

2]平均扈間変形速度 $(\widetilde{V})$ の目标值。

3] 截荷装置の性能上の制約から、最大利力時の軸力比（計測值）は、Mタイフ

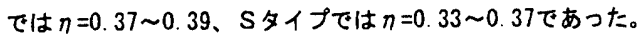

\section{(2) 使用材料}

試験体に用いたコンクリートの材料試験結果を表 2 に、鉄筋の材 料試験結果を表 3 に示す。コンクリート材料試験はJIS A 1108に、 鉄筋材料試験はJIS Z 2241に準処し実施した。以後、これらの材料 試験を静的載荷材料試験と称する。

なお、静的載荷材料試験でコンクリート供試体に生じるひずみ速

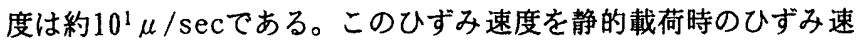
度レベルと考え、材料強度の上昇率や部材耐力の增大率をとる際の 基準のひずみ速度とした。

(3) 加力方法

加力装置を図 2 に、加力スケジュールを図 3 に示す。加力に際し ては、目標層間変形角を 5 段階設定し、アクチュエータを変位制御 して各層間変形角ごとに 2 サイクルずつ、計10サイクルの正弦波に よる正負交番渐增絽り返し加力を行い、試験体の柱部分に逆対称モ 一メントを発生させた。この際、平均層間変形速度を 2 種類設定し、 層間変形の時刻歴において連続する波形の正負のピークを結んだ傾 きが $\widetilde{V}=0.01 \mathrm{~cm} / \mathrm{sec} 、 な ら ひ ゙ に \widetilde{V}=10 \mathrm{~cm} / \mathrm{seckなるようにした。}$ 前者を静的加力、後者を動的加力と称する。この動的加力時の平均 層間変形速度は、地震時に建筑物の柱部材に生じるひずみ速度を再 現できるように地震応答解析結果を踏まえて設定した4)。軸力につ いては、シリーズ I の場合は、水平加力前に目標軸力比に相当する $\eta=0.3$ 軸力を静的油圧ジャッキにより試験体に載荷した。Mタイ プ、Sタイプともに、試験体 3 体のうち 2 体を動的加力に用い、水 平加力中は軸力用の油压ジャッキを荷重制御したが、加力装置の性 能上の制約から、結果的に变動軸力となった。残り1体を静的加力 に用い、水平加力中は、動的加力試験体 2 体の平均軸力と層間変形 との関係に従い変動軸力を載荷した。なお、動的加力試験体 2 体の 軸力履歷は近似していだ)。一方、シリーズIIの場合は、軸力の影 響をできる限り減ずるために、油圧ジャッキによる軸力の導入を零 としたか、加力装置の性能上の制約から、鉛直滑動装置の自重5.2 $\mathrm{tf}$ （ $\eta=0.02 \sim 0.03 ）$ が一定軸力として試験体に作用した。

\section{(4) 計測方法}

層間変位はインダクタンス型変位計により、鉄筋のひずみはひず

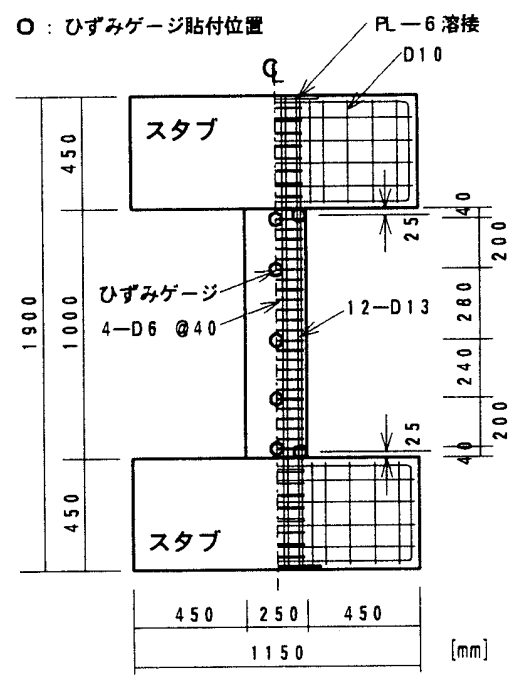

[Mタイプ, MSF-1, MDF-1, 2]

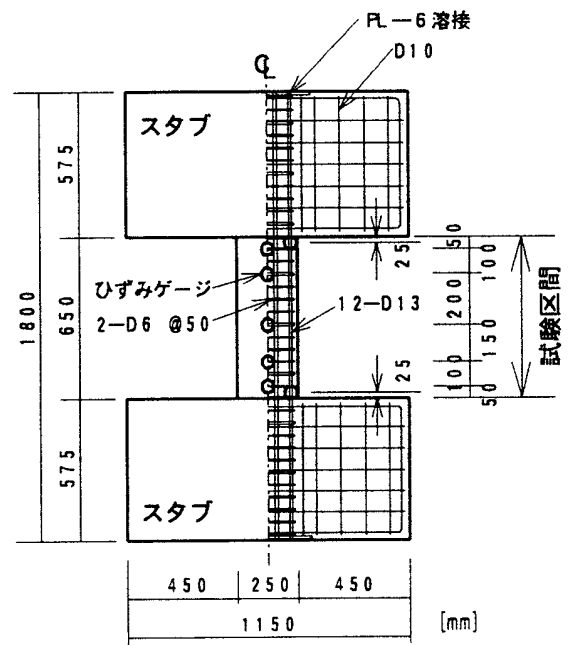

[Sタイプ, SSF-1, SDF-1，2]

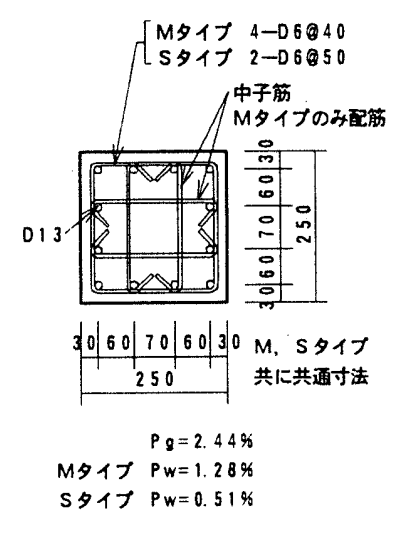

图 1 試験体の形状・寸法、およひ配筋 
表 2 コンクリートの材料試験結果

\begin{tabular}{|c|c|c|c|c|c|}
\hline シリーズ & 試験体 & $\begin{array}{l}\text { 圧縮強度 } \\
\left(\mathrm{kgf} / \mathrm{cm}^{2}\right)\end{array}$ & $\begin{array}{l}\text { 割裂強度 } \\
\left(\mathrm{kgf} / \mathrm{cm}^{2}\right)\end{array}$ & $\begin{array}{l}\text { 弾性係数 } \\
\left(\mathrm{kg} f \mathrm{~cm}^{2}\right)\end{array}$ & $\begin{array}{l}\text { 材令 } \\
\text { (日) }\end{array}$ \\
\hline \multirow{3}{*}{ I } & MSF-1 & 289 & \begin{tabular}{|l|}
26.2 \\
\end{tabular} & $1.98 \times 10^{5}$ & 45 \\
\hline & $M D F-1$ & 284 & 26.3 & $1.94 \times 10^{5}$ & 36 \\
\hline & MDF-2 & 293 & 24.6 & $1.95 \times 10^{5}$ & 40 \\
\hline \multirow{3}{*}{ I } & SSF-1 & 310 & 24.8 & $2.03 \times 10^{5}$ & 71 \\
\hline & $S D F-1$ & 301 & 25.1 & $1.97 \times 10^{5}$ & 53 \\
\hline & SDF-2 & 304 & 24.7 & $1.90 \times 10^{5}$ & 65 \\
\hline \multirow{8}{*}{ II } & SSC-2 & 323 & 29.0 & $2.71 \times 10^{5}$ & 27 \\
\hline & SDC-2 & 350 & 30.4 & 2. $84 \times 10^{5}$ & 28 \\
\hline & SSC-3 & 361 & 32.1 & 2. $81 \times 10^{5}$ & 39 \\
\hline & SDC-3 & 357 & 26.3 & 2. $71 \times 10^{5}$ & 44 \\
\hline & SSC-4 & 354 & 30.6 & 2. $80 \times 10^{5}$ & 47 \\
\hline & SDC-4 & 354 & 31.5 & 2. $81 \times 10^{5}$ & 53 \\
\hline & SSC-5 & 360 & 28.8 & 2. $90 \times 10^{5}$ & 58 \\
\hline & SDC-5 & 360 & 28.1 & 2. $98 \times 10^{5}$ & 62 \\
\hline
\end{tabular}

[注] 試験方法：JIS A 11081二準拠、試験值：供試体 3本

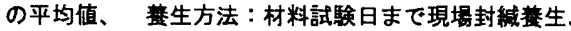
シリーズII では、SSC-2のみ他の試験体とコンクリート の打設日が異なる

\section{表 3 鉄筋の材料試験結果}

\begin{tabular}{|c|c|c|c|c|c|}
\hline シリース & 呼び名 & $\begin{array}{c}\text { 降伏強度 } \\
\left(\mathrm{kgf} / \mathrm{cm}^{2}\right)\end{array}$ & $\begin{array}{c}\text { 栙伏ひずみ } \\
\left(\times 10^{-6}\right)\end{array}$ & $\begin{array}{c}\text { 引張強度 } \\
\left(\mathrm{kgf} / \mathrm{cm}^{2}\right)\end{array}$ & $\begin{array}{c}\text { 破断伸び } \\
(\%)\end{array}$ \\
\hline I & $D 13$ & 3280 & 1840 & 4870 & 28.1 \\
& $D 6$ & $4290^{*}$ & - & 5490 & 22.3 \\
\hline II & $D 16$ & 3665 & 2354 & 5566 & 23.6 \\
& $D 6$ & 3846 & 2060 & 5558 & 23.6 \\
\hline
\end{tabular}

[注] 試験方法：JIS Z 22411準拠、試験值：供詰体 3本 の平均值 $* 0.2 \%$ off set

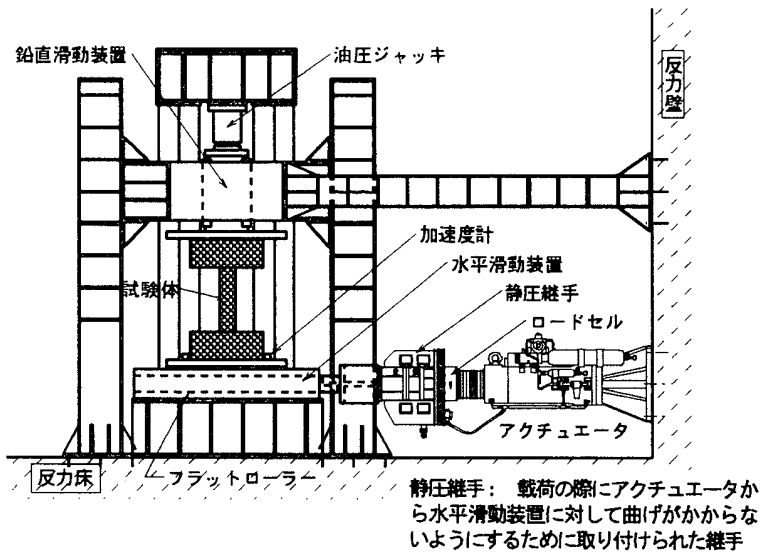

図2 加力装置

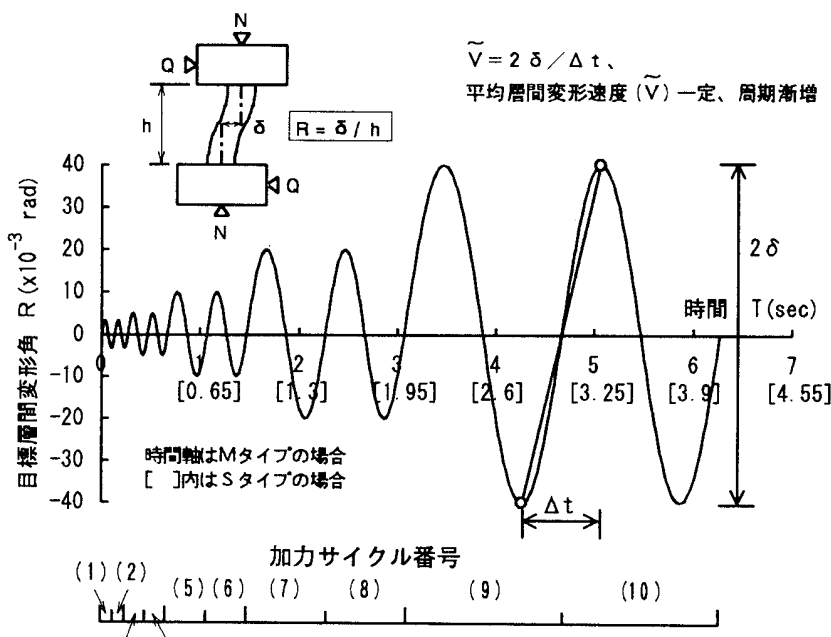

(3)(4)

図 3 加カスケジュール
みゲージにより計測した（図1参照）。せん断力は、ロードセルで 検出された荷重から、水平滑動装置ならびに静圧継手の質量と水平 滑動装置上で計測された加速度との積から得た慣性力を引くことに よって求めた。また、ひび制れの進展状況は高速写真て確認した。 なお、計測インターバルは、Mタイプでは $1 / 645$ 秒、Sタイプでは1/ 495 秒である。

\section{2 実験結果}

\section{（1）動的加力時のひずみ速度}

柱主筋とフープ筋のせん断力ーひずみ速度 $(\mathrm{Q}-\dot{\varepsilon})$ 曲線の例之 して、動的加力を行ったSDC-4について図4に示す。図中のひずみ 速度は、図 5 に示す方法により、柱頭、柱脚位置で柱主筋に貼付し たひずみゲージと、柱中央－柱頭間位置でフープ筋に貼付したひず みゲージから得られた鉄筋の軸方向ひずみについて、計測インター バル間の变化量を計測インターバルて除して求めた。得られた柱主 筋の $Q-\dot{\varepsilon}$ 曲線における最大ひずみ速度は、柱頭で約 $5 \times 10^{4}$ 、柱脚 で約 $7 \times 10^{4} \mu / \mathrm{sec}$ でった。せん断力がピークに近づくにつれてひ ずみ速度は減少するものの、最大耐力時のひずみ速度は、柱主筋の 引張側では約 $1 \times 10^{4} \mu / \mathrm{sec} 、$ 圧縮側では約 $7 \times 10^{3} \mu / \mathrm{sec}$ であった。ま た、柱主筋の引張降伏時のひずみ速度は、柱脚で約 $2 \times 10^{4} \mu / \mathrm{sec} て$ あった。一方、フープ筋のQ $Q-\dot{\varepsilon}$ 曲線は、变動が大きく安定してい ない部分があるものの、最大ひずみ速度は柱主筋之同様に約 $5 \times 10^{4}$ $\mu / \mathrm{sec}$ であり、最大耐力時のひずみ速度は約 $1 \times 10^{4} \mu / \mathrm{sec}$ でっった。 ここて、、コンクリートのひずみ速度について述べる。最大耐力時に おける材端部ての压縮側柱主筋のひずみ速度は約 $7 \times 10^{3} \mu / \mathrm{sec}$ であ った。コンクリートと柱主筋との付着強度が完全でると仮定する と、コンクリートのひずみ速度は、柱主筋のひずみ速度と等しいと 考えることができる。また、柱やはりのようなアスペクト比（h/D、 $\mathrm{h}$ :柱高さ、D:柱成）を有する部材であれば、材端部の圧縮縁を結ふ: ストラットのひずみ速度は、圧縮側柱主筋のひずみ速度とほぼ等し い。したがって、コンクリートのひずみ速度は、圧縮側の柱主筋の

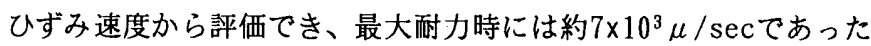
と考えられる。

他の動的加力試験体の最大耐力時のひずみ速度は、Mタイプ、 $\mathrm{S}$

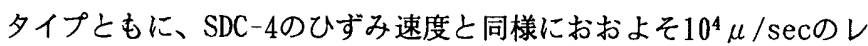
ベルにあった。

\section{（2）破壊状況}

目標軸力を軸力比にして0.3に設定したシリーズ I の破壊状況に ついてみると、曲け破壊型に計画したMタイプ(MSF-1、MDF-1、2、 せん断余裕率：1.28)の場合は、動的加力と静的加力とではひび割 れの様相は若干異なっているものの、材端部で柱主筋の降伏状況、 コンクリートの圧壊状況は類似しており、3試験体とも曲げ破壊之 判定した。せん断破壊型に計画したSタイプ(SSF-1、SDF-1、2、せ ん断余裕率：0.84)の場合は、静的加力を行ったSSF-1ではせん断ひ び割れが拡大し、部材中央付近で柱主筋が座屈するほど損稘が激し かったが、動的加力を行ったSDF-1では、せん断ひび割れが拡大し たものの柱主筋の座屈はみられなかった。SDF-2ではせん断ひび割 れの他、付着ひび割れが若干発生したものの、せん断ひび割れが拡 大し破壊した。3 試駼体とも柱主筋が降伏したが、破壊状況ならび に最大耐力以後の耐力の低下傾向から、最終破壊モードはせん断破 壊と判定した。 

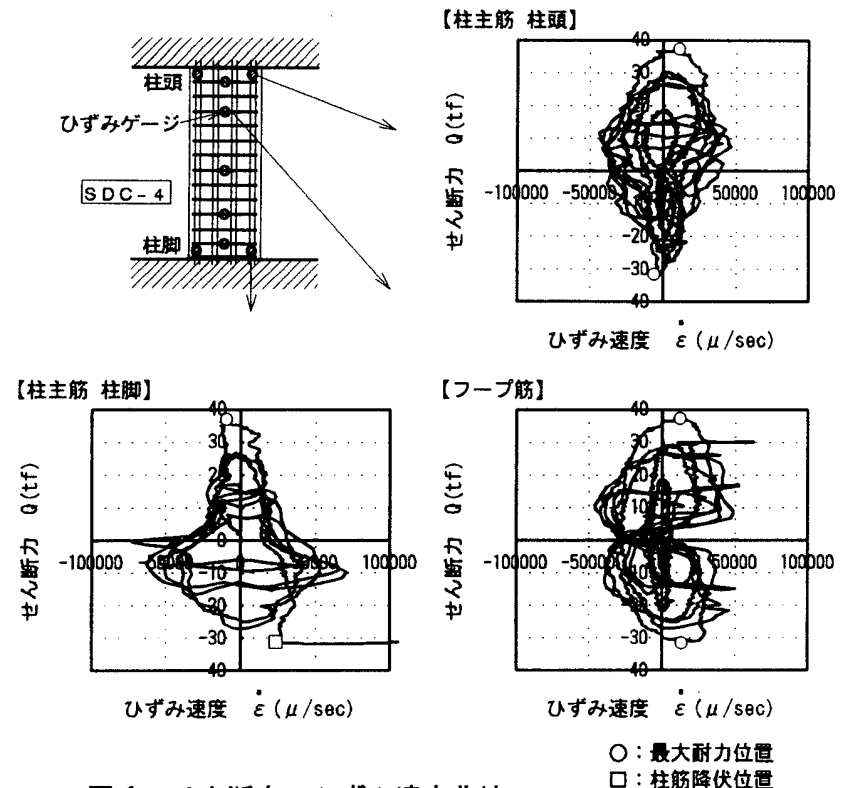

図4 せん断カーひずみ速度曲線

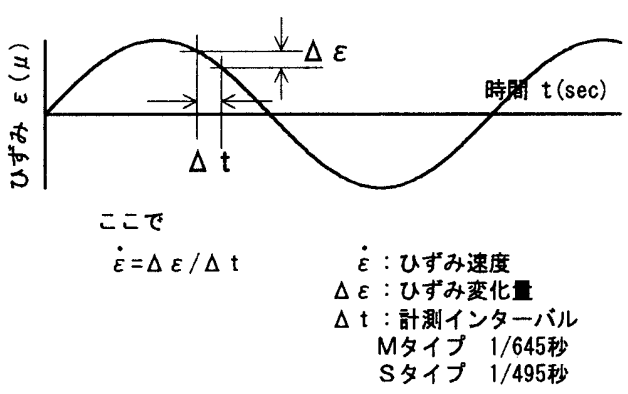

図 5 ひずみ速度の求め方

$\eta=0.02 \sim 0.03$ に相当する一定軸力て、配筋が異なる組み合わせ であるシリーズII (SSC-2〜 5、SDC-2〜5、せん断余裕率 : $0.80 \sim 0.92$ )の破壊状況についてみると、静的加力を行ったSSC-2〜5の各試験 体では、せん断ひび割れが拡大し破壊に至った。このとき、SSC-2、 SSC-4、SSC-5では柱主筋が降伏したものの、最大耐力以後に臫力低 下がみられ、また破壊状況はせん断破壊の様相を示したことから、 SSC-2〜5の最終破壊モードはせん断破壊と判定した。動的加力を行 ったSDC-2では、材端部からおおよそD（D:柱成）の範囲にせん断ひ び割れが発生し、これと柱主筋とが交差する付近から柱中央に向け 付着ひび割れが発生し拡大した。続いて柱中央にせん断ひび割れが 拡大したため、破壊モードは付着ひび割れが卓越したせん断破壊と 判定した。同一配筋モテルである静的加力のSSC-2とは異なった破 壊過程をたどった。一方、SDC-3〜5では、SDC-3で僅かに付着ひび 割れがみられた他は、それぞれが対応する静的加力試験体と同様な 破壊状況であった。したがって、SDC-2〜5の最終破壊モードはせん 断破壊と判定した。

\section{(3) 最大耐力}

加力実験で得られた最大耐力と、静的加力に対する動的加力での 最大耐力の增大率、ならびに最大耐力時の軸力比を表 4 に示す。

シリーズ I（ $\eta=0.33 \sim 0.39 ）$ の曲げ破壊型のMタイプでは、静 的加力を行ったMSF-1に対し、動的加力を行ったMDF-1、MDF-2の最 大耐力は、それぞれ1.08、1.09倍に增大した。また、せん断破壊型 のSタイプでは、静的加力を行ったSSF-1に対し、動的加力を行っ
表 4 最大耐力、最大耐力の增大率、最大耐力時の軸力比

\begin{tabular}{|c|c|c|c|c|}
\hline \multicolumn{5}{|c|}{ シリーズ I } \\
\hline & 加力 & 最大耐力 & 増大半 & 軸力比 \\
\hline 試験体 & 方法 & $\begin{array}{l}\text { Otu } \\
\text { (tf) }\end{array}$ & $\begin{array}{l}\text { 动的 } \\
\text { 静的 }\end{array}$ & $\eta$ \\
\hline MSF-1 & 静的 & 20.5 & \multirow{3}{*}{$\begin{array}{l}1.09 \\
\text { (平均) }\end{array}$} & 0.39 \\
\hline MDF-1 & 動的 & 22.2 & & 0.38 \\
\hline MDF-2 & 動的 & 22.4 & & 0.37 \\
\hline SSF-1 & 静的 & 27.7 & \multirow{3}{*}{$\begin{array}{l}1.23 \\
\text { (平均) }\end{array}$} & 0.33 \\
\hline SDF-1 & 䦽的 & 33.2 & & 0.36 \\
\hline SDF-2 & 動的 & 34.9 & & 0.37 \\
\hline
\end{tabular}

\begin{tabular}{|c|c|c|c|c|}
\hline \multicolumn{5}{|c|}{ シリーズII } \\
\hline 験体 & $\begin{array}{l}\text { 加力 } \\
\text { 方法 }\end{array}$ & \begin{tabular}{|c|} 
最大耐力 \\
Otu \\
(tf $)$
\end{tabular} & 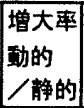 & $\begin{array}{c}n \\
n\end{array}$ \\
\hline C -2 & & 23.7 & & \\
\hline SDC-2 & 動的 & 30.1 & & 0.02 \\
\hline SSC-3 & 静的 & 26.2 & & 0.02 \\
\hline SDC-3 & 勤的 & 30.9 & .10 & 0.02 \\
\hline SSC-4 & 静的 & 31.7 & & 0.02 \\
\hline SDC-4 & 杼的 & 36.6 & & 0.02 \\
\hline SSC-5 & 静的 & 35.2 & & 0.02 \\
\hline SDC-5 & 動的 & 39.6 & & 0.02 \\
\hline
\end{tabular}

たSDF-1、SDF-2の最大耐力は、それぞれ1.20、1.26倍に增大した。

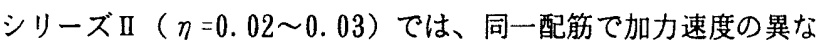
る試験体を比較すると、コンクリートの圧縮強度の差が $8 \%$ \%った $\mathrm{SSC}-2\left(\sigma_{\mathrm{B}}=323 \mathrm{kgf} / \mathrm{cm}^{2}\right)$ ¿SDC- $2\left(\sigma_{\mathrm{B}}=350 \mathrm{kgf} / \mathrm{cm}^{2}\right)$ を除くコンクリ 一ト強度が互いにほぼ等しい 3 組の試験体(SSC-3〜 $5 、$ SDC-3〜 5 : $\left.\sigma_{\mathrm{B}}=354 \sim 361 \mathrm{kgf} / \mathrm{cm}^{2}\right)$ の場合には、動的加力の最大耐力は静的加力 に比べて1.13〜1.18倍に增大した。

以上の実験結果から、曲げ破壊型、せん断破壊型ともに、動的加 力では静的加力に比べて最大耐力は増大し、この最大耐力の増大 率は、加力実験において生じた破壊形式（曲げ破壊、せん断破壊） の違いにより異なり、さらに軸力レベルや鉄筋比の違いによっても 異なることがわかる。

（4）せん断耐力の増大率と鉄筋比および軸力比との関係

せん断破壊型のSタイプの試験体について、静的加力に対する動 的加力での最大耐力の增大率と鉄筋比および軸力比との関係を図 6 に示す。ここて、最大耐力の増大率は、静的加力に対する動的加力 てのせん断耐力の比でるが、静的加力のSSC-2之動的加力のSDC-2 では、SSC-2のコンクリートの圧縮強度はSDC-2に比べ約 $8 \%$ 低く、 見かけ上、せん断耐力の増大率が他の試験体間の増大率に比べて大 きな值を示す結果となった。そこて、SSC-2のコンクリート強度と して (1)実強度の場合亡、(2)SDC-2の強度と同一と仮定した場合の 2 種の強度をとり、修正荒川mean式 ${ }^{8)}$ 、終局強度型耐震設計指針・ 同解説の $\mathrm{A}^{\text {法 }^{9}}{ }^{\text {) }}$ 、ならびに倉本・南が提案したせん断耐力式 ${ }^{10)}$ か らせん断耐力を求め、これらからコンクリート強度の上昇によるせ ん断耐力の増大率を算出し、SSC-2のせん断耐力の実験值を補正す ることとした。すなわち、それら 3 式によれば、本試験体の場合に は、コンクリートの圧縮強度が $8 \%$ 上昇するとせん断耐力は2. $5 \sim 3.7$ \%上昇するのて、SSC-2のせん断耐力の実験值を $3 \%$ 上昇させ、SDC -2のせん断耐力の実験值との比をとり最大耐力の增大率とした。ま た、SSF-1とSDF-1、SDF-2ては、最大酎力時の軸力比に差がみられ、 これが最大酎力に影響を与えていると考えられた。そこで、SSF-1 の軸力比をSDF-1、2の軸力比に対応させて、せん断耐力の実験值を 補正することとした。すなわち、修正荒川mean式によると、本試験 体の場合には、軸力比が $11 \%$ 上昇するとせん断耐力は $2.2 \%$ 增大す るのて、、SSF-1のせん断酎力の実験值を $2 \%$ 上昇させ、SDF-1および SDF-2のせん断耐力の実験值との比をとり最大耐力の增大率とし 


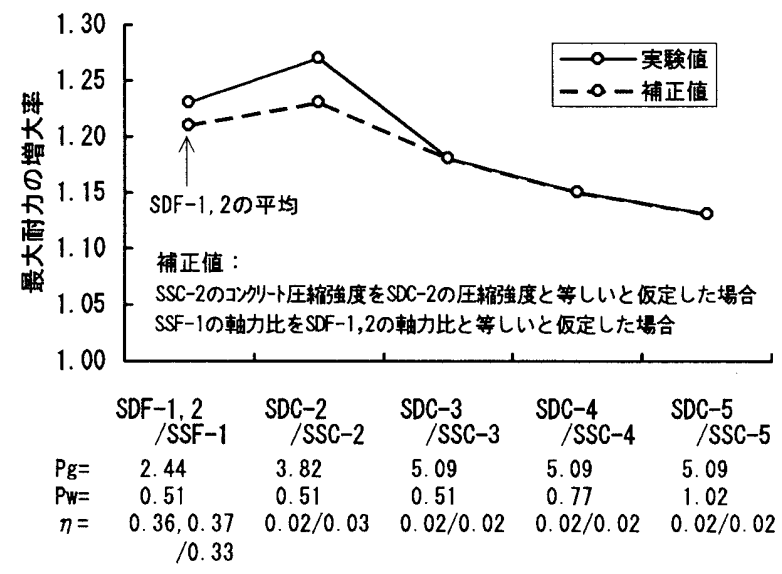

図 6 最大耐カの増大率と鉄筋比および軸力比との関係

た。その增大率の補正值を図 6 に併記している。

図 6 から、柱主筋比が一定の場合には、最大耐力の増大率は 1.13 $(\mathrm{Pw}=1.02 \%) \sim 1.18(\mathrm{Pw}=0.51 \%)$ を変動しており、フープ筋比 が小さいほど最大耐力の増大率は上昇傾向を示すことがわかる。一 方、フープ筋比が同一でかつ軸力比がほぼ同一の場合には、柱主筋 比が小さい方が最大耐力の増大率は上昇した。また、柱主筋比が幾 分異なるもののフープ筋比が同一の場合には、軸力比の違いによら ずほぼ同程度の増大率を示した。

\section{3.ひずみ速度の影響による最大耐力の増大率の検討 3.1 せん断耐力の増大率}

せん断破壊したSタイプの試験体を対象に、動的加力では静的加 力に比較して最大耐力が増大する理由を、倉本・南のせん断耐力式10) を用いて以下に検討する（付式 1参照）。なお、倉本・南式は塑性 理論を応用したせん断耐力式であり、主筋、せん断補強筋およびコ ンクリート斜め圧縮束材からなるトラス機構による負担せん断力と、 コンクリート斜め圧縮束材（以下、ストラットと称す）のみによる アーチ機構の負担せん断力との累加によってせん断耐力を与えるも のであり、アーチ機構による負担せん断力に対して軸力の効果を考 慮している。

（1）フープ筋比によるせん断耐力の增大率の変動

倉本・南式から得られたせん断耐力の計算値においてアーチ機構 とトラス機構が負担するせん断力、ならびに最大耐力の実験值を図 7 に示す。この際、動的加力試験体では、ひずみ速度が材料強度に 与える影響を考慮し、最大耐力時のひずみ速度のレベルに応じて材 料強度を割り增して負担せん断力を求めた。すなわち、地震時に柱 部材に生じると想定されるひずみ速度（ $\left.\left.\dot{\varepsilon}=10^{4} \sim 10^{5} \mu / \mathrm{sec}\right)^{1)} \sim 3\right)$ て は、既往の研究 $\left.{ }^{1}\right) 、 2 ， 4$ ) から、コンクリートの圧縮強度は静的載

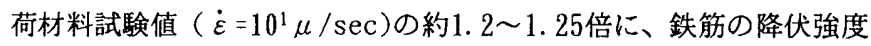
は約1.1〜1.15倍に上昇することが知られている。したがって、加 力実験において最大耐力時に柱部材に生じていたと考えられるひず

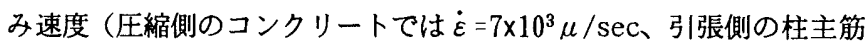
およびフープ筋では $\dot{\varepsilon}=1 \times 10^{4} \mu / \mathrm{sec、}$ 、 4 参照）を考慮し、コンク リートの圧縮強度を1.2倍に、鉄筋の降伏強度を1.1倍に割り增した。

倉本・南式で得られたせん断耐力の計算値に対する実験値の比を とると1.0〜1.17であり、静的加力、動的加力ともに計算值は実験

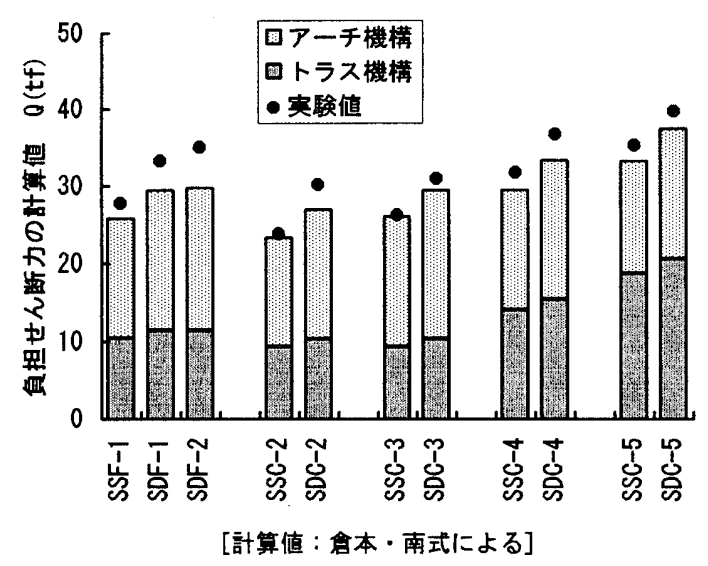

図 7 アーチ機構とトラス機構による負担せん断カの比較

值と概ね良い対応を示している。このうち、軸力比がおおよそ0.02 て、主筋比が一定でフープ筋比が変動するSSC-3とSDC-3〜SSC-5 とSDC-5の計算值についてみると、アーチ機構とトラス機構がある 割合をもってせん断力を負担している。当然のことながらフープ筋 比が增大するとトラス機構による負担せん断力が增大し、フープ筋 比が減少するとアーチ機構による負担せん断力が増大している。こ のような関係においては、トラス機構が支配的になると、せん断力 は主としてフープ筋により負担されるため、せん断耐力の増大率は フープ筋の降伏強度の上昇率に対応することとなる。したがって、 加力実験中にフープ筋に生じていたひずみ速度のレベルであれば、 せん断耐力の増大率はおおよそ1.1に近づくことが予想される。ま た、アーチ機構が支配的になると、せん断力は主としてコンクリー トにより負担されるため、せん断耐力の増大率はストラットのコン クリート強度の上昇率にほぼ対応すると考えられる。したがって、 加力実験中に材端部の圧縮縁に生じていたひずみ速度のレベルでは、 せん断耐力の増大率はおおよそ1.2に近づくことが予想される。こ れは以下の理由による。すなわち、図 8 に示すように、材端部では ひずみ速度の影響でコンクリート強度が上昇し、ストラットの応力 が増大する。一方、部材中央付近ではストラットに沿うひずみ速度 は小さく、その影響によるコンクリート強度の上昇も小さいものの、 材端部での応力上昇と釣り合うようストラットの面積が增大してい るものと推定できる。このため、動的加力ではアーチ作用による負 担せん断力は増大し、これに伴い部材のせん断耐力も増大寸る。そ
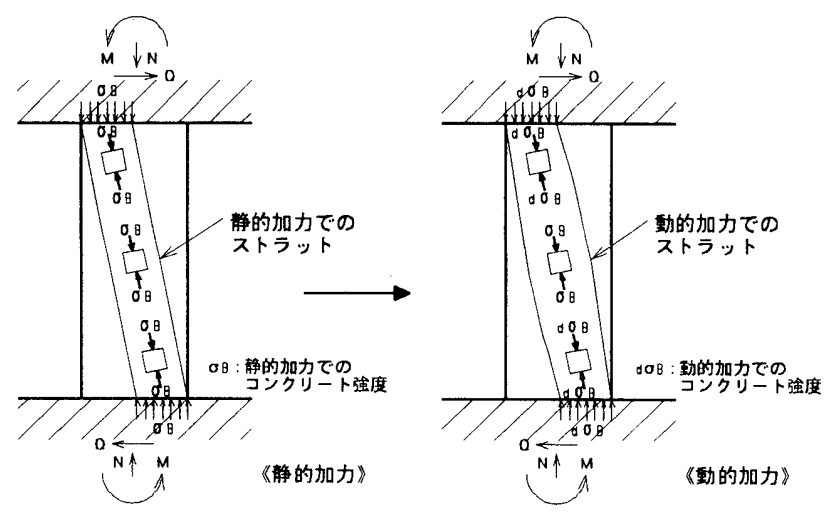

図 8 ひずみ速度の影響によるストラット幅の変化 
の增大率は、材端部でのコンクリート強度の上昇率と等価となる。

以上から、加力実験の軸力レベル程度で、かつせん断耐力におい てトラス機構とアーチ機構の負担するせん断力が混在する場合には、 ひずみ速度の影響によるせん断耐力の增大率はおおよそ1.1〜1.2の 間にあるといえる。このため、図 6 に示すように、SDC-3〜SDC-5 の試験体( $\mathrm{PW}=0.512 \sim 1.024)$ では、最大耐力の実験值が 1.13 倍〜 1.18倍を変動したものと考えられる。

\section{（2）軸力の有無によるせん断耐力の増大率}

軸力が作用する場合と作用しない場合のせん断耐力に与えるひず み速度の影響を比較するため、柱主筋比が幾分異なるものの、フー プ筋比が同一である試験体を選び、静的加力のSSF-1とSSC-2、動的 加力のSDF-1、2亡SDC-2の最大耐力を図 9 に示す。この際、比較す る試験体どうしの材料強度を合わせ、上記2.2(4)の場合と同様な考 え方で最大酎力の実験值を補正した。

軸力が作用している試験体のせん断耐力から軸力が作用していな い試験体のせん断耐力を引くことによって、軸力の効果による負担 せん断力が求められるとすると、図 9 に示すように、静的加力での 軸力の効果によるせん断力の負担分 (a) と動的加力での負担分 (bとc の平均)は近い値を示した。後者と前者の差か、軸力の効果による 負担せん断力に対するひずみ速度の影響による増大分と考えられる が、後者の前者に対する比は1.15であり、コンクリート強度の上昇 率に近似していた。これは以下の理由によるものと考えられる。す なわち、軸力が作用する場合には、アーチ機構におけるストラット の面積は、静的加力、動的加力にかかわらず軸力の効果により同量 増大する。また、動的加力では、3.1(1)に示したように、ひずみ速 度の影響によりコンクリート強度は上昇し、これに応じてストラッ トの応力は増大する。このため、静的加力に対する動的加力でのア 一千機構による負担せん断力の增大率は、コンクリート強度の上昇 率に比例すると考えられる。また、軸力が作用しない場合も、動的 加力では、コンクリート強度の上昇に応じてストラットの応力は增 大するため、アーチ機構による負担せん断力の増大率はコンクリー 卜強度の上昇率に比例する。したがって、動的加力てのアーチ機構 による負担せん断力の増大率は、軸力の有無によらず、ひずみ速度 の影響によるコンクリート強度の上昇率に比例すると解釈できる。 このため、アーチ機構による負担せん断力の一部を成す軸力の効果 による負担せん断力の増大についても、ひずみ速度の影響によるコ ンクリート強度の上昇に対応し、図 9 に示した動的加力での增大率 は、コンクリート強度の上昇率に近似していたと考えられる。

一方、終局強度型耐震設計指針・同解説 $\left.{ }^{9}\right)$ によれば、フープ筋比 がある程度以上の場合には、軸力の効果によるせん断耐力の増大は ほとんどないと述べられている。このため、トラス機構が支配的な 場合には、トラス機構による負担せん断力は、軸力の影響をほと んど受けないものと仮定できる。したがって、動的加力でのトラ ス機構による負担せん断力の増大率は、軸力の有無によらず、ひ ずみ速度の影響によるフープ筋の降伏強度の上昇率に比例すると 考えられる。

以上から、動的加力では、ひずみ速度の影響によりせん断耐力は 増大し、その增大率は、軸力の有無によらずほぼ同程度と考えられ る。このため、図6において、SSF-1に対するSDF-1、2、ならびにSSC -2に対するSDC-2の最大耐力の增大率は近い值を示したといえる。

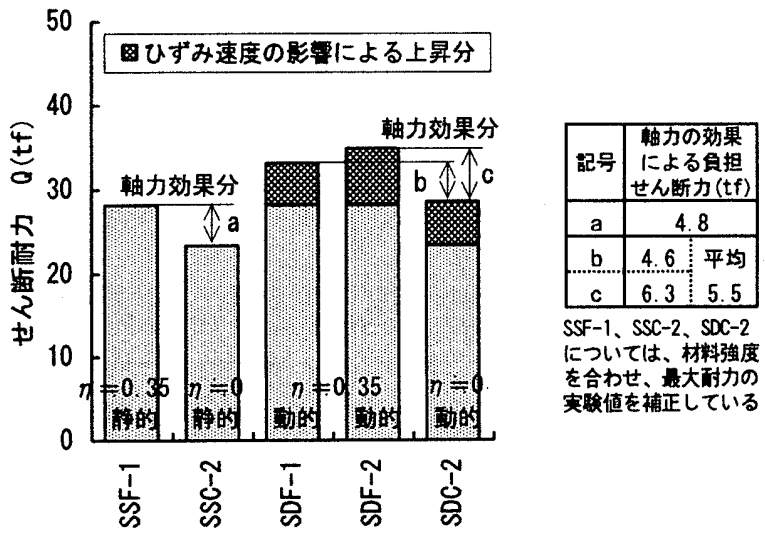

図9軸力の効果による負担せん断力の比較

\section{(3) せん断耐力の增大率}

上記 (1)、（2)から、地震時に部材に生じると想定されるひずみ速 度の範囲（ $\dot{\varepsilon}=10^{4} \sim 10^{5} \mu / \mathrm{sec} ）$ では、せん断耐力の増大率は、軸 力の有無によらず、せん断酎力に対してトラス機構による負担せん 断力が支配的な場合には、フープ筋の降伏強度の上昇率（1.10〜1.15 程度）に、アーチ機構による負担せん断力が支配的な場合には、コ ンクリートの圧縮強度の上昇率（1.20 1.25程度）に近つき、その間 に挟まれた領域ではおおよそ1.1〜 1.25を変動すると考えられる。

\section{2 曲げ耐力の増大率}

上記2. 2(3)で、曲げ破壊型の場合、静的加力を行ったMSF-1に対 し、動的加力を行ったMDF-1、2では、最大耐力はそれぞれ1.08、 1.09倍に増大したことを述べた。この最大耐力の增大率は、同一の ひずみ速度が生じたときの柱主筋の降伏強度の上昇率1)、2)にほぼ 一致している。本加力実験では、最大耐力時の軸力は軸力比にして 約0.3〜0.4であったが、このような条件下では、曲げ耐力の増大は、

概ね柱主筋の降伏強度の上昇に対応すると考えてよい。

一方、筆者らは、曲げ破壊型の R C 部材を対象に、ひずみ速度の 影響による材料強度の上昇を考慮したファイバーモデルよる断面 解析を行った。この際、加力実験で網羅できなかったひずみ速度と 軸力比の領域も含め、曲率速度（ひずみ速度）ならびに軸力比と曲 げ䙳力の増大率との関係について検討した。断面解析の概要と結果 については文献 6 で報告したが、本論では、この解析結果の一部を 引用し、曲け酎力ならびにせん断耐力の增大率と破壊モードとの関 係について以下に検討する。なお、断面解析の方法、材料強度の設 定等については文献 6 に詳しい。ここで、曲率速度とは、単位時間 あたりの曲率增分を単位時間で除したもので、平面保持の仮定の下 ではずみ速度と対応する。

解析対象とした断面の要素分割と材料定数をまとめて図10に、解 析の際にパラメータとした曲率速度と軸力比を表 5 に示す。曲率速 度としては、静的加力実験の際の曲率速度と同程度のレベル（ $\dot{\phi}$ $\left.=10^{-6} 1 / \mathrm{cm} \cdot \mathrm{sec}\right)$ から、地震時に建築物の部材に生ずると想定され る曲率速度の最大値（ $\dot{\phi}=10^{-1} 1 / \mathrm{cm} \cdot \mathrm{sec} ）$ まで範囲で 6 段階の解 析ケースを設定した。また、表 6 には、曲率速度に対応する最外端 の柱主筋のひずみ速度のレベルを示している。軸力は、軸力比にし て $0.0 、 0.15 、 0.3 、 0.45 、 0.6 、 0.75$ の 6 段階設定した。 静的加力時の曲率速度に相当する $\dot{\phi}=10^{-6} 1 / \mathrm{cm} \cdot \mathrm{sec}$ 、すなわち、

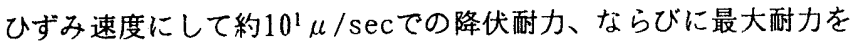




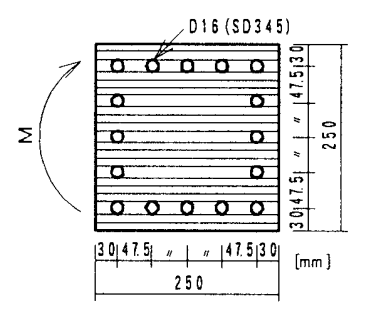

コンクリート

$\sigma B=360 \mathrm{kgf} / \mathrm{cm}^{2}$

$\sigma_{\mathrm{t}}=28.8 \mathrm{~kg} \mathrm{f} / \mathrm{cm}^{2}$

$E_{c}=2.9 \times 10^{5} \mathrm{~kg} \mathrm{f} / \mathrm{cm}^{2}$

鉄筋

$\sigma \sigma y=3665 \mathrm{~kg} f / \mathrm{cm}^{2}$

$E_{s}=2.1 \times 10^{6} \mathrm{kgf}^{2} \mathrm{~cm}^{2}$

図10 要素分割および材料定数

表 5 解析パラメータ

\begin{tabular}{|c|c|c|}
\hline $\begin{array}{c}\text { 曲率速度 } \\
\begin{array}{c}\dot{\phi} \\
(1 / \mathrm{cm} \cdot \mathrm{sec})\end{array}\end{array}$ & $\begin{array}{c}\text { 軸力比 } \\
n\end{array}$ \\
\hline $10^{-6}$ & & 0.00 \\
\hline $10^{-5}$ & & 0.15 \\
\hline $10^{-4}$ & $\times$ & 0.30 \\
\hline $10^{-3}$ & & 0.45 \\
\hline $10^{-2}$ & & 0.60 \\
\hline $10^{-1}$ & 0.75 \\
\hline
\end{tabular}

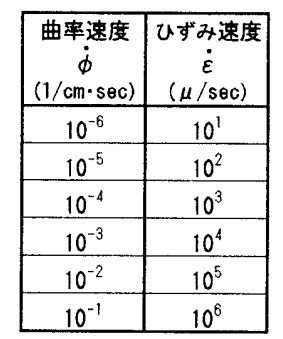

*貶外端の柱主能位要

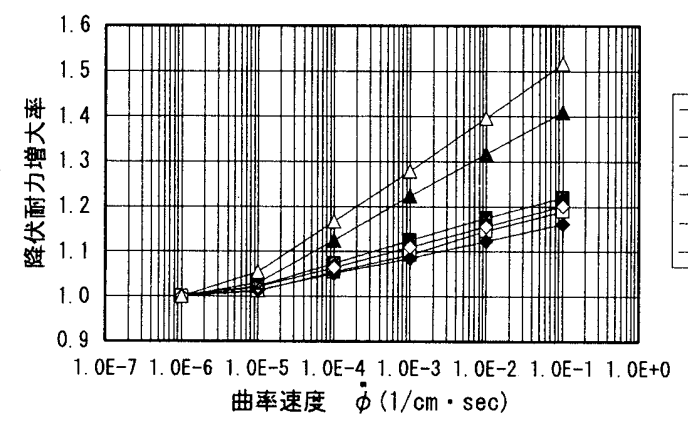

图11降伏耐力の増大率と曲率速度との関係

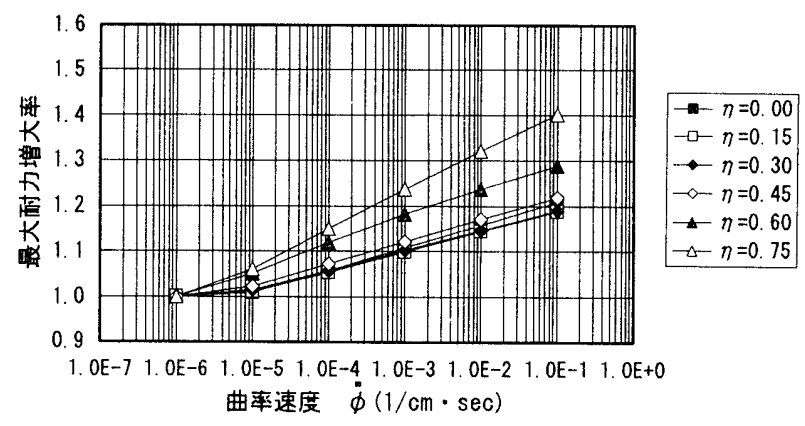

図12最大耐力の増大率と曲率速度との関係

基準としたときの各解析ケースでの降伏耐力の増大率と曲率速度と の関係を図11に、最大耐力の増大率と曲率速度との関係を図12に示 す。ここで、降伏耐力は、部材の最外端の主筋が引張降伏または圧 縮降伏したときの曲げ耐力である。

降伏耐力の増大率と曲率速度との関係は、 $\phi=10^{-2} 1 / \mathrm{cm} \cdot \sec (\dot{\varepsilon}$ $\fallingdotseq 10^{5} \mu / \mathrm{sec}$ ）におりる降伏耐力の増大率を例にとると、軸力比が 0.0 〜0.3 (釣り合い軸力以下) では1.18〜1.12であり、軸力比が大き くなるにつれて增大率は僅かではあるが低下するものの、 $\eta=0.45$ では增大率は上昇傾向に転じ1. 16に、 $\eta=0.6 、 0.75$ (釣り合い軸力 以上）では1.32、1.40に急激に上昇した。最大耐力の増大率につい

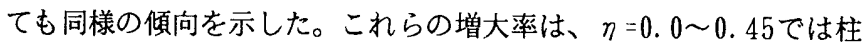

主筋強度の上昇率に近似し、 $\eta=0.6$ ではコンクリート強度の上昇率 に近く、 $n=0.6$ 以上では材料強度の上昇率を上回るといえる。これ は、以下のように説明される。すなわち、釣り合い軸力を下回る軸 力で、部材断面の中立軸は、軸力レベルが同一であれば曲率速度 の違いによらずほぼ近い位置にある。材料強度は中立軸に関する曲 率速度に応じて上昇するのて、、曲率速度が速い場合の図心に関する 抵抗モーメント（曲げ耐力）の増大率は、材料強度の上昇率にほぼ 近い值となる。一方、釣り合い軸力を上回る軸力では、軸力レベル が同一であっても、曲率速度が上昇すると、中立軸位置は引張縁側 から図心側に移動する。このため、曲率速度が速い場合の図心に関 する抵抗モーメントの増大率は、中立軸に関する曲率速度に応じた 材料強度の上昇率に対応せず、その増大率は材料強度の上昇率をも 上回る方向へ変動する。

以上の実験結果ならびに断面解析結果から、地震時に部材に生じ ると想定される曲率速度（ひずみ速度にして $10^{4} \sim 10^{5} \mu / \mathrm{sec}$ ）の範 囲では、降伏耐力は、釣り合い軸力以下で約1. 1 1.2倍に増大し、 釣り合い軸力以上では約1.2１.4倍に増大する。また、最大耐力は、 釣り合い軸力以下で約1.1〜1.15倍に増大し、釣り合い軸力以上 では約1.15〜1.3倍に増大すると考えられる。

\section{4.ひずみ速度の影響による最大耐力の増大と破壊モードとの関係}

3 章で示した R C 部材のせん断耐力と曲げ耐力の増大率、ならび に最大酎力の関係について、地震時のひずみ速度のおおよその上限 と想定される $10^{5} \mu / \sec の$ 場合を例にとり図13〜図15に示し、最大 耐力の変動亡破壊モードとの関係を以下に考察する。

(1) せん断耐力に対してアーチ機構による負担せん断力が支配的て、 かつ鈞り合い軸力を下回る軸力を受ける場合（Case A) には、図13 に示すように、曲げ耐力は1. 15倍程度の増大にとどまるのに対し、 せん断耐力は1.25倍程度增大すると考えられる。このため、静的載 荷時にせん断耐力が曲げ耐力を上回っている場合には、地震時に最 大耐力の逆転現象によって破壊モードが变化する可能性は少ない。 (2) トラス機構による負担せん断力が支配的で、かつ釣り合い軸力 を上回る高軸力を受ける場合（Case B ）には、図14に示すように、 曲げ耐力は1. 3倍程度增大するのに対し、せん断耐力は 1.15 倍程度 の増大にとどまると考えられる。したがって、地震時には、曲げ耐 力がせん断耐力を上回ることによって、曲げ破壊型からせん断破壊 型に破壊モードが移行する可能性がある。

(3) トラス機構による負担せん断力が支配的で、かつ釣り合い軸力 を下回る軸力を受ける場合（CaseC）には、図15に示すように、曲 げ酎力およびせん断耐力はともに1. 15倍程度增大すると考えられる。 したがって、地震時に曲げ耐力とせん断耐力の大小関係が逆転する ことは少なく、破壊モードが変化する可能性は少ない。

(4) アー千機構による負担せん断力が支配的で、かつ釣り合い軸力 を上回る高軸力を受ける場合（Case D ）には、図15に示すように、 曲げ耐力は 1.3 倍程度増大し、せん断耐力は 1.25 倍程度増大する之 考えられる。この場合、曲げ耐力の増大率はせん断耐力の增大率を 僅かに上回るため、地震時には曲げ耐力とせん断耐力の大小関係が 逆転し、破壊モードが変化する可能性もある。

また、Case A〜CaseDに包含される条件の下（図15において網掛 けの領域）では、静的載荷時にせん断耐力が曲げ耐力を上回ってい 


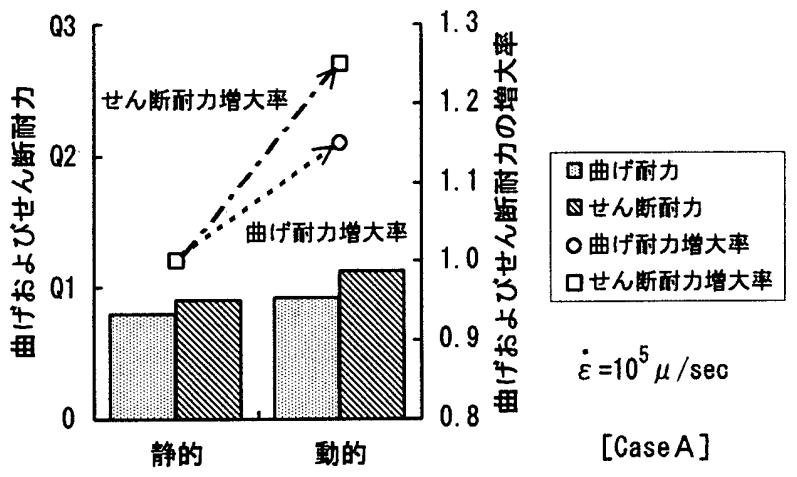

図13 アーチ機構が支配的でかつ釣り合い軸力を下回る 場合の曲げ耐力とせん断耐カとの関係（模式図）

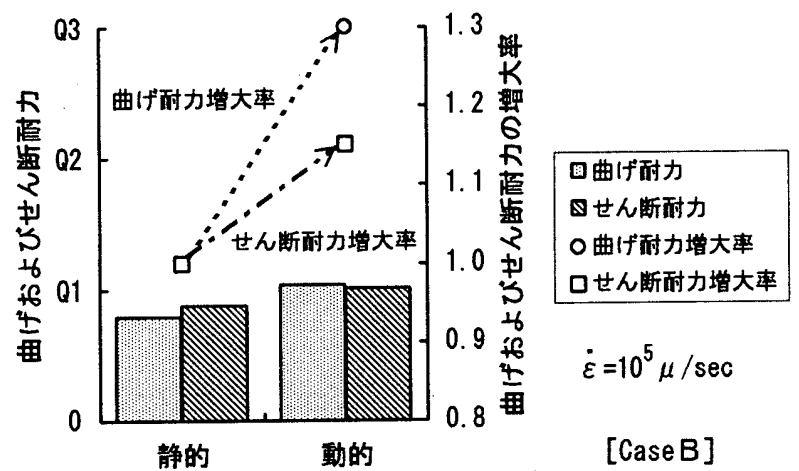

図14トラス機構が支配的でかつ釣り合い軸力を上回る 場合の曲げ耐カとせん断耐カとの関係（模式図）

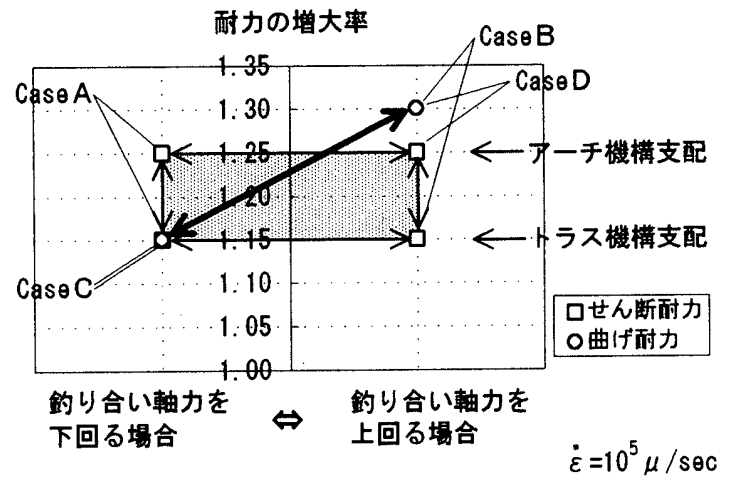

図15 ひずみ速度の影響による曲げ頋カとせん断耐力の増大率

る亡、地震時に破壊モードが曲げ破壊型からせん断破壊型に変化す る可能性は少ないものの、Case Bに近づくにつれて、すなわち、軸 力比にして約 0.6 を回るような高軸力て、かつトラス機構による 負担せん断力がせん断耐力の大部分を担う場合には、破壊モードが 変化する可能性が高まるといえる。

\section{5.曲げ酎カに対するせん断耐力の必要余裕度}

4 章に示したように、地震時には、部材に生じるひずみ速度の影 響により破壊モードが変化し、設計時に意図した破壊モードが形成 されない場合が予想される。したがって、地震時に R C 部材に対し て曲げ破壊型を保証するためには、以下に示すように、せん断酎力 は、ひずみ速度の影響による耐力の增大分として、曲げ耐力に対し て15\%以上の余裕度を確保する必要がある。
[ひずみ速度のレベル： $\left.\dot{\varepsilon}=10^{5} \mu / \mathrm{sec}\right]$

(1) 鈞り合い軸力を下回る場合

・トラス機構が支配

・アーチ機構が支配

mI $/ \mathrm{sl}=1.15 / 1.15=1$

(2) 釣り合い軸力を上回る場合

・トラス機構が支配

$\mathrm{ml} / \mathrm{sl}=1.3 / 1.15=\underline{1.13}$

必要な 余裕度

・アーチ機構が支配 $\mathrm{ml} / \mathrm{sI}=1.3 / 1.25=1.04$

ここて、

\section{III：静的加力に対する動的加力での曲げ耐力の増大率}

sI：静的加力に対する動的加力でのせん断耐力の増大率

また、 R C 造建築物の柱部材は、通常釣り合い軸力比以下で設計 されるが、地震時には外柱では軸力は変動し、釣り合い軸力比以上 に上昇する可能性がある。たとえば、30階建ての建筑物を対象とし

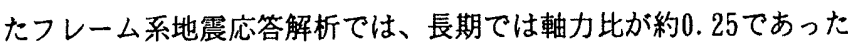
ものが地震時 (レベル 2 ) には約 0.6 まで変動した ${ }^{11) 。 こ の よ う に ~}$ 軸力が変動する場合、上記 3.2 のファイバーモデルによる断面解析 結果では、図16に示すように、曲げ酎力はおおよそ1.2〜1.3倍に增大 する。このことも考え合わせると、長期に作用する軸力レベルの大 きさにかかわらず、せん断耐力は曲け耐力に対して15\%以上の余裕度 を確保する必要がある。

6. まとめ

地震時の鉄筋コンクリート部材の最大耐力は、部材に生じるひず み速度の影響を受けて、静的載荷時の最大耐力よりも増大する。し かし、せん断耐力之曲げ酎力の増大率はそれぞれ異なり、地震時に おける最大耐力の大小関係は静的載荷時の関係から変化する可能性 がある。このため、設計時には曲げ破壊型の破壊モードを想定して いるものの、地震時にはせん断破壊型になることも予想される。し たがって、地震時に曲げ破壊型の破壊モードを保証するためには、 軸力レベルにかかわらず、ひずみ速度の影響による耐力の増大分と して、静的載荷時の曲げ耐力に対するせん断耐力の余裕度を15\%以 上確保する必要がある。

なお、地震時に曲げ破壊型の破壊モードを保証するためには、付 着耐力に及ぼすひずみ速度の影響についても検討し、付着破壊と曲 げ破壊ならびにせん断破壊との関係を明らかにして、曲け耐力に対

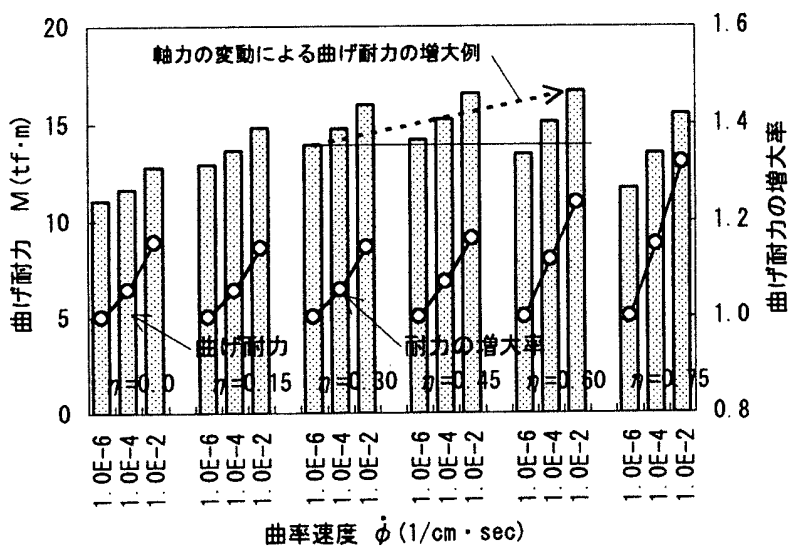

図16 軸カが変動するときの曲げ耐カと曲げ耐力の増大率 
する付着酎力の必要余裕度を設定する必要があるが、これについて は今後の課題としたい。

\section{謝辞}

本論の作成にあたり、建設省建築研究所の倉本 洋博士には有益 なご助言をいただきました。ここに記して謝意を表します。

\section{参考文献}

1）小谷俊介：鉄筋コンクリートにおける載荷速度の影響、コンクリート 工学、Vol. 21、No. 11、pp. 23 34、1983. 11

2 ）岩井 哲、吉田 望、中村 武、若林 實 : 構造部材の挙動に及ほす 載荷速度の影響に関する実験的研究（その 1 コンクリートと鋼材の応 力ー歪関係に及ぼす歪速度の影響）、日本建築学会論文報告集、第 314 、 pp. 102 111、1982. 4

3）細矢 博、中江晃彦、北島圭二、小駒 勲、中埜良昭：実大 3 首鉄筋 コンクリート造骨組の振動台実験（その 7 地震時に部材に生じるひず み速度の検討）、日本建築学会大会学術講演梗概集、構造IV、pp. 815 816、1996.9

4) 細矢 博、安倍 勇、岡田恒男、北川良和：铁筋コンクリート部材の 耐力と破壊性状に及ぼすひずみ速度の影響に関する研究 一材料実験と 高軸力が作用する柱部材の水平加力実験一、コンクリート工学論文集、 第 4 巻第 2 号、pp. 43 56、1993. 7

5) 細矢 博、安倍 勇、岡田佰男、北川良和：鉄筋コンクリート部材の 耐力之破壊性状に及ぼすひずみ速度の影篦に関する研究 一せん断破壊 型柱部材の静的及び動的水平加力実検一、コンクリート工学論文集、第 5 巻第 1 号、pp. 39 49、1994. 1

6 ）細矢 博、岡田恒男、北川良和、中埜良昭、郎澤文俊：ひする速度の 影䈉を考虑したファイバーモデルによる鉄筋コンクリート部材の断面解 析、日本建築学会構造系論文集、第482号、pp. 83 92、1996.4

7）日本建築センター：構造計算指針・同解説、pp. 230 233、1991年
8 ）日本建築学会：铁筋コンクリート終局強度設計に関する資料、pp.70 ７1、1987年

$9 ）$ 日本建築学会：鉄筋コンクリート造建物の終局強度型耐震設計指針・ 同解説、pp. 106 121、1990年

10）倉本 洋、南 宏一：塑性理論を応用した鉄筋コンクリート部材の実 用せん断設計式、日本建築学会構造系論文報告集、第417号、pp. 31 45、 1990. 11

11）跦奥村組技術研究年報、No. 15（別冊）、PP. 152 155、1989

\section{【付録】}

用いた倉本・南式を以下に示す。

Qs $=\mathrm{b} \cdot \mathrm{d} \cdot \mathrm{pw} \cdot \sigma \mathrm{wy}+(\gamma-2 \alpha \cdot \Psi) \mathrm{b} \cdot \mathrm{D} \cdot \mathrm{Fc} \ldots \ldots \ldots \ldots \ldots \ldots$ 付式 1

ただし、 $Q s \leqq(b \cdot d \cdot F c / 2) \gamma / \alpha$

ここで、

$\mathrm{n} \leqq 0.5-2 \Phi$ よき

$\gamma=\left\{\sqrt{ }\left[4(\mathrm{n}+2 \Phi)(1-\mathrm{n}-2 \Phi)+\eta^{2}\right]-\eta\right\} / 2$

$\mathrm{n}>0.5$-2Фのとき

$\gamma=\alpha=\left(\sqrt{ }\left[1+\eta^{2}\right]-\eta\right) / 2$

$\mathrm{b}$ : 部材断面の幅、 $\mathrm{d}$ : 主筋間淂

$\mathrm{pw}$ : せん断補强筋比

$\sigma \mathrm{wy}:$ 女ん断補強筋の降伏強度

$\Psi:$ せん断補強笳係数 $[=\mathrm{pw} \cdot \sigma \mathrm{wy} / \mathrm{Fc}]$

Fc : コンクリートの圧縮强度

$\mathrm{n}:$ 無次元化軸力 $[=\mathrm{N} /(\mathrm{b} \cdot \mathrm{D} \cdot \mathrm{Fc})]$

$\Phi:$ 引張主筋係数 $[=\mathrm{pt} \cdot \sigma \mathrm{y} / \mathrm{Fc}]$

$\sigma \mathrm{y}$ : 主筋の降伏強度、 $\quad \eta$ : 柱長さ比 $[=\mathrm{L} / \mathrm{D}]$

$\mathrm{L}:$ 部材の長さ、 $\mathrm{D}:$ 部材断面のせい

$(\gamma / \alpha-2 \Psi) \mathrm{b}:$ ストラットの有効断面幅 